Original Article

\title{
Occurrence of Hymenolepis diminuta: a potential helminth of zoonotic importance in murid rodents
}

\author{
Ocorrência de Hymenolepis diminuta: um helminto potencial de importância \\ zoonótica em roedores murídeos
}

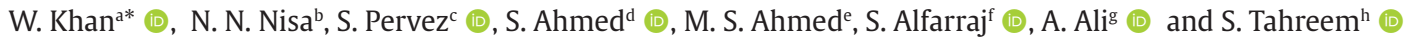 \\ a University of Malakand, Zoology Department, Dir (Lower), Pakistan \\ ${ }^{\mathrm{b}}$ Pakistan Agricultural Research Council - PARC, Southern Zone-Agricultural Research Centre - SARC, Vertebrate Pest Control Institute - VPCI, \\ Karachi, Pakistan \\ 'Shaheed Benazir Bhutto Women University Peshawar, Department of Biochemistry, Khyber Pakhtunkhwa, Pakistan \\ ${ }^{\mathrm{d}}$ Hazara University, Department of Zoology, Mansehra, Pakistan \\ e University of Swabi, Department of Zoology, Swabi, Pakistan \\ ${ }_{\mathrm{f}}^{\mathrm{f}}$ King Saud University, College of Science, Zoology Department, Riyadh, Saudi Arabia \\ ${ }^{\mathrm{g}}$ MirPur University of Science and Technology, Department of Zoology, Azad Jammu and Kashmir, Pakistan \\ ${ }^{\mathrm{h}}$ University of Agriculture, Department of Zoology, Wildlife and Fisheries, Faisalabad, Pakistan
}

\begin{abstract}
The study reveals the prevalence of a potential rodent-borne zoonotic helminth species, Hymenolepis diminuta in commensal rodents caught from irrigated and rain-fed areas of Swat, Pakistan. Three hundred and fifty rodents (269 rats and 81 mice) trapped during vegetative, flowering/fruiting and mature/harvesting stages of crops were studied from 2011-2013. Hymenolepisdiminuta eggs were identified on the basis of their shape, size, colour and markings on the surface of the egg shell and three pairs of embryonic hook-lets. Overall prevalence of $H$. diminuta was $3.14 \%$ ( $n=11 / 350)$. The highest prevalence $3.49 \%$ ( $n=5 / 143$ ) of $H$. diminuta was noted at harvesting stages of the crops whereas the lowest $2.59 \%(n=2 / 77)$ during vegetative stage. Infection was higher in males $3.25 \%(n=7 / 215)$ than females $2.96 \%(n=4 / 135)$. Adult rodents were highly infected while no sub-adult was found infected. Infection was higher in mice $3.70 \%(3 / 81)$ than rats $2.69 \%$ (8/269) while no significance ( $\mathrm{p}=1.0000: 0.1250$ to $32.00 \mathrm{CI}$ ). Rats and mice appears to show the most suitable reservoirs by hosting $H$. diminuta a zoonotic helminth. The presence of these rodents in all possible habitats can act as a main channel of transferring parasites through various habitats and can pose a hazard to humans in the area.
\end{abstract}

Keywords: zoonotic parasite, Hymenolepis diminuta, commensal rodents, murid, agricultural ecosystem.

\section{Resumo}

O estudo revela a prevalência de uma espécie potencial de helmintos zoonóticos transmitidos por roedores, Hymenolepis diminuta, em roedores comensais capturados em áreas irrigadas e alimentadas pela chuva de Swat, Paquistão. Trezentos e cinquenta roedores (269 ratos e 81 camundongos) presos durante os estágios vegetativo, floração/frutificação e maturidade/colheita das safras foram estudados de 2011-2013. Ovos de Hymenolepisdiminuta foram identificados com base em sua forma, tamanho, cor e marcações na superfície da casca do ovo e três pares de anzóis embrionários. A prevalência geral de $H$. diminuta foi de 3,14\% ( $n=11 / 350)$. A maior prevalência 3,49\% $(n=5 / 143)$ de $H$. diminuta foi observada na fase de colheita das lavouras, enquanto a menor 2,59\% $(n=2 / 77)$ durante a fase vegetativa. A infecção foi maior nos homens $3,25 \%(n=7 / 215)$ do que nas mulheres $2,96 \%$ ( $n=4 / 135$ ). Roedores adultos foram altamente infectados, enquanto nenhum subadulto foi encontrado infectado. A infecção foi maior em camundongos 3,70\% (3/81) do que em ratos 2,69\% (8/269), embora sem significância ( $\mathrm{p}=1,0000$ : 0,1250 a 32,00 CI). Ratos e camundongos parecem mostrar os reservatórios mais adequados hospedando $\mathrm{H}$. diminuta um helmintos zoonótico. A presença desses roedores em todos os habitats possíveis pode atuar como um canal principal de transferência de parasitas através de vários habitats e pode representar um perigo para os humanos na área.

Palavras-chave: parasita zoonótico, Hymenolepis diminuta, roedores comensais, murídeo, ecossistema agrícola.

*e-mail: walikhan.pk@gmail.com

Received: August 10, 2020 - Accepted: October 7, 2020 


\section{Introduction}

Rodents of the family Muridae act as an important reservoirs of ectoparasites as well as helminths of potential importance (Bordes et al., 2013). Rodent borne diseases like others such as malaria, tuberculosis, AIDS and helminthiasis also effect human population and are considered as neglected diseases. Diseases caused by helminths parasites potentially impacts on physical, nutritional, mental, and intelligent development of children (WHO, 1987). Most of the helminths are known for the public health importance such as echinococcosis, taeniasis, trichinosis, schistosomiasis, filariasis, opisthorchiasis and hymenolepiasis with the aid of potential role of murid rodents as reservoirs for parasites of zoonotic importance.

Several reports on $H$. nana infection in Swat area of Pakistan have been published as Khan et al. (2011, 2017a, b, 2018a, b, 2019a, b), Khan and Khan (2015) and Noor un Nisa et al. (2012) but no report is available on H.diminuta infection in man, however some other studies such as Marangi et al. (2003) and Rohela et al. (2012) have reported the presence of $H$. diminuta in humans. Arthropod fleas, coleopteran beetles, caterpillars, and millipedes, are known as the intermediate hosts (Heicher and Gallati, 1978; Andreassen et al., 1999). The cysticercoid contaminated food of the intermediate hosts when ingested become the leading source of infection to human beings. Though, $H$. diminuta does not normally show severe symptoms, however, mild to moderate infection cannot cause any symptoms, whereas heavy infection can cause giddiness, anorexia, intestinal disorders, and diarrhea Waikagul and Thairungroj, 1997).

Rodents in most parts of the globe have been have been studied for the presence of $H$. diminuta but studies on this zoonotic parasite is lacking in Pakistan. Synanthropic rodents in Pakistan have been studied for their zoonosis by Hayat and Akhtar (1999), Khatoon et al. (2004), Yaqoob et al. (2007), Mushtaq-ul-Hassan et al. (2008) and Rafique et al. (2009). This research aimed to know the occurrence of $H$. diminuta, a potential helminth of zoonotic importance in rats and mice of agricultural ecosystem of Swat, district, Pakistan.

\section{Materials and Methods}

Three hundred and fifty rodents (269 rats and 81 mice) were trapped during vegetative, flowering/ fruiting and mature/harvesting stages of crops (maize, rice and potatoes) studied from 2011-2013. These rodents were caught with live traps, killed with chloroform, and examined for helminths within 40 minutes of death. The captured specimens of the rodents were by applying the keys provided by Roberts (1997). H. diminuta (the rat tapeworms) recovered from the small intestine was fixed in 70\% ethyl alcohol. Parasites were pressed between two glass slides during fixation of which formalin acetic acid solution was used for 24-hours. The parasites were then processed in a series of graded alcohol. Mayer's Carmalum or Semicon's Carmine were used for staining, Clove-oil was used for cleaning the specimens and Canada balsam or preserva-slide was used for mounting of the parasites.
The parasite specimens were measured length by width in millimeter. The tapeworms (adults + proglottids) were identified by the keys provided by Hayat and Akhtar (1999), Foreyt (2001). The shape, size, colour and marking on the surface of the egg shell and three pairs of embryonic hook-lets were carefully examined throughout the entire experiments. The data was analyzed for the P-value with 95\% CI using Graph Pad Prism 5.

\section{Results}

Current research reveals $3.14 \%$ prevalence of $H$. diminuta. Slight variances were detected within the areas. Infection rate of parasite in rodents of rain-fed areas $2.99 \%(n=5 / 350)$ and irrigated areas 3.27\% ( $n=6 / 350)$ was shown in Table 1. Rats and mice trapped from potatoes showed highert prevalence rate $4.28 \%(n=3 / 70)$ than rice $3.12 \%(n=3 / 96)$ and maize $2.71 \%(n=5 / 184)$ Table 2 . There was a significant $(\mathrm{p}=0.021)$ variation in the number of rodents caught in different crop stages while no such association was noted for the infections. Data regarding sex, ages and species of the rodents did not show significance difference. Infection was higher in mice $3.70 \%$ (3/81) than rats $2.69 \%(8 / 269)$ but the difference was not significant $(\mathrm{P}=1.0000(0.1250$ to $32.00 \mathrm{CI}$ ). Table 1 . The highest peak in prevalence was during the harveststage $3.49 \%(n=5 / 143)$ and lowest during vegetative stage $2.59 \%(n=2 / 77)$. The highest crop wise peak prevalence was observed in rodents from potatoe fields $4.28 \%(n=3 / 70)$ followed by rice $3.12 \%(n=3 / 96)$ and the lowest was in rats/mice captured from maize fields $2.71 \%$ $(n=5 / 184)$ as indicated in Table 2 . The number of rodents captured from both the localities and their infection was not significantly different $(\mathrm{P}<0.05)$.

\section{Discussions}

A number of murid rodent species have been investigated as $H$. diminuta reservoirs in Southeast Asia. The $3.14 \%$ ) prevalence of $H$. diminuta recorded in the present study was lower than those of earlier studies published in various regions of the globe. In contrast to the findings of the present study, higher prevalence rates of $\mathrm{H}$. diminuta was reported as 38\% Kumarasinghe et al. (2006); 36.9\% Stojcevic et al. (2004); 35.8\% Abu-Madi et al. (2005); and $30.7 \%$ Kassa and Assefa (2000) respectively. According to the study by Rafique et al. (2009) the prevalence of $\mathrm{H}$. diminuta ranged between 20 and60\% which differs markedly from the results of present study. The prevalence rate of the present study was in accordance with those of Kia et al. (2001) and Waugh et al. (2006) who reported $H$. diminuta prevalence of 11.1 and $3.8 \%$ respectively.

The highest prevalence was observed during mature/ harvesting stage and lowest during vegetative stage. The highest crop wise prevalence peak was observed in rodents from potatoes fields followed by rice while the lowest was in rats/mice captured from maize fields. The probability of contamination by rodents is much higher during the crop maturity/harvesting stages when 
Table 1. Cropping stage, sex, age and species related prevalence of $H$. diminuta in rodents trapped in rain-fed and irrigated areas of Swat, Pakistan.

\begin{tabular}{|c|c|c|c|c|c|c|c|c|c|c|}
\hline \multicolumn{11}{|c|}{ Localities } \\
\hline & \multirow{2}{*}{$\begin{array}{c}\text { Parameters } \\
\text { Cropping } \\
\text { stages }\end{array}$} & \multicolumn{3}{|c|}{ Rain-fed } & \multicolumn{3}{|c|}{ Irrigated } & \multirow{2}{*}{ 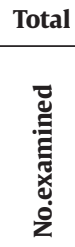 } & \multirow{2}{*}{ 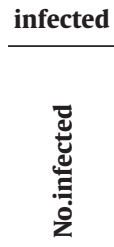 } & \multirow{2}{*}{$\begin{array}{l}\% \\
\%\end{array}$} \\
\hline & & 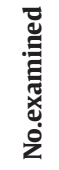 & 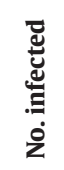 & $\%$ & 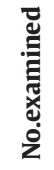 & 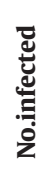 & $\%$ & & & \\
\hline \multirow{3}{*}{ Seasons } & Vegetative & 35 & 1 & 2.85 & 42 & 1 & 2.38 & 77 & 2 & 2.59 \\
\hline & $\begin{array}{l}\text { Flowering/ } \\
\text { fruiting }\end{array}$ & 59 & 2 & 3.38 & 71 & 2 & 2.81 & 130 & 4 & 3.07 \\
\hline & Harvesting & 73 & 2 & 2.73 & 70 & 3 & 428. & 143 & 5 & 3.49 \\
\hline \multicolumn{2}{|c|}{ P-value (Chi-square test) } & \multicolumn{6}{|c|}{$0.9465(0.1100)$} & & & \\
\hline \multirow{2}{*}{ Sex } & Male & 105 & 3 & 3.15 & 110 & 4 & 5.45 & 215 & 7 & 3.25 \\
\hline & Female & 62 & 2 & 3.25 & 73 & 2 & 5.47 & 135 & 4 & 2.96 \\
\hline \multicolumn{2}{|c|}{ P-Value $(95 \% \mathrm{CI})$} & \multicolumn{6}{|c|}{0.6515 (0.06364 to 8.839$)$} & & & \\
\hline \multirow{2}{*}{ Age } & Adults & 79 & 5 & 6.39 & 99 & 6 & 6.06 & 178 & 11 & 6.17 \\
\hline & Sub-adults & 88 & 0 & 0 & 84 & 0 & 0 & 172 & 0 & 0 \\
\hline \multicolumn{2}{|c|}{ P-Value (95\% CI) } & \multicolumn{6}{|c|}{$0.9089(-17.30$ to 16.30$)$} & & & \\
\hline \multirow{2}{*}{ Species } & Rats & 128 & 4 & 3.12 & 141 & 4 & 2.83 & 269 & 8 & 2.69 \\
\hline & Mice & 39 & 1 & 2.56 & 42 & 2 & 4.76 & 81 & 3 & 3.70 \\
\hline \multicolumn{2}{|c|}{ P-Value (95\% CI) } & \multicolumn{6}{|c|}{$1.0000(0.1250$ to 32.00$)$} & & & \\
\hline Total & & 167 & 5 & 2.99 & 183 & 6 & 3.27 & 350 & 11 & 3.14 \\
\hline
\end{tabular}

CI: Confidence of interval.

Table 2. Prevalence of $H$. diminuta in rodents trapped in rain-fed and irrigated areas of Swat (crops wise).

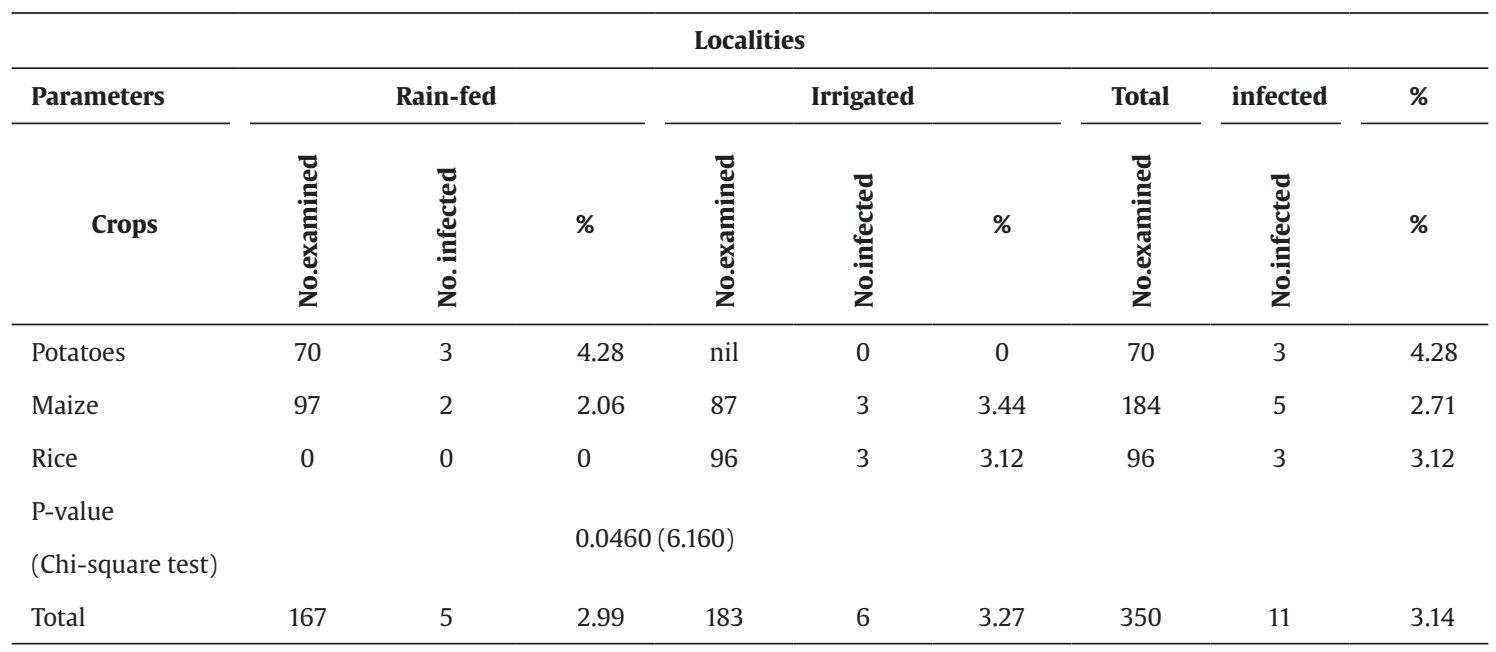

agricultural products are to be stored, than the flowering/ fruiting and vegetative stages.

The higher prevalence of H.diminuta observed during the mature/harvesting stage might be due to reason that intermediate host contact intensity is higher than in other cropping periods. A higher rate (17.6\%) of H.diminuta infection was recorded by Abu Madi et al. (2001) in brown rats with no seasonal relation, which is not in accordance to the present investigation. Prevalence of $H$. diminuta was higher in male rats/mice (3.25\%) than females (2.96\%) 
trapped at both of localities of the present study area, matchable findings were reported by Goswami et al. (2009), Nama and Parihar (1976), Maki and Yanagisawa (1987), Yen et al. (1996) and Waugh et al. (2006).This is because, males are more mobile and aggressive, getting more chance to contact infection from infected intermediate hosts at the visited localities than the females. In contrast Stojcevic et al. (2004) observed high prevalence in females (62.4\%) than males (37.7\%) in Croatia.

According to age infection was observed primarily in adult's hosts (6.17\%) while no infection was recovered in sub-adult rodents. A study conducted by Abu-Madi et al. (2005) reported more adults were infected than subadults, the study by Madi et al., found that the numbers of $H$. diminuta was nearly double in adults than juveniles of both species of rodents. The higher infection in adult than juveniles might be due to more feed intake and wandering behavior of the former. Infection rate was higher (45.5\%) in adult rodents as compared to juveniles (13.7\%) which is not in accordance with the present study. Rise in the infection rate with increasing age was also noted Stojcevic et al. (2004).Current study demonstrate that mice were highly infected (3.70\%) than rats (2.69\%). Higher prevalence of H.diminuta was investigated in black rats in Nigeria (Mafiana et al., 1997).

Current study reveals a high infection rate of $H$. diminuta in mice than in rats which may be due to the commensal behavior of mice. Mice exploit mostly the house hold environments than rats. Present study highlights the role of rodents as a bridge for human-rodent-helminth interaction and as a leading source for transmission of rodent-borne parasitic diseases to humans living in close relationship with rodents.

\section{Acknowledgements}

Vertebrate Pest Control Institute, Pakistan Agricultural Research Council, Southern Zone of Agricultural Research Centre has acknowledged for cooperation during the study. The authors extend their appreciation to the researchers supporting project number (RSP-2020/7) King Saud University, Riyadh, Saudi Arabia.

\section{References}

ABU-MADI, M.A., BEHNKE, J.M., MIKHAIL, M., LEWIS, J.W. and AL-KAABI, M.L., 2005. Parasite populations in the brown rat Rattus norvegicus from Doha, Qatar between years: the effect of host age, sex and density. Journal of Helminthology, vol. 79, no. 2, pp. 105-111. http://dx.doi.org/10.1079/JOH2005274. PMid:15946389.

ABU-MADI, M.A., LEWIS, J.W., MIKHAIL, M., EL-NAGGER, M.E. and BEHNKE, J.M., 2001. Monospecific helminth and arthropod infections in an urban population of brown rats from Doha, Qatar. Journal of Helminthology, vol. 75, no. 4, pp. 313-320. http://dx.doi.org/10.1017/S0022149X01000488. PMid:11818046.

ANDREASSEN, J., BENNET-JENKINS, E.M. and BRYANT, C., 1999. Immunology and biochemistry of Hymenolepis diminuta. Advances in Parasitology, vol. 42, pp. 223-275. http://dx.doi. org/10.1016/S0065-308X(08)60150-5. PMid:10050274.
BORDES, F., HERBRETEAU, V., DUPUY, S., CHAVAL, Y., TRAN, A. and MORAND, S., 2013. The diversity of microparasites of rodents: a comparative analysis that helps in identifying rodent-borne rich habitats in Southeast Asia. Infection Ecology E' Epidemiology, vol. 3, no. 1, pp. 20178. http://dx.doi.org/10.3402/iee.v3i0.20178. PMid:23577229.

FOREYT, W.J., 2001. Veterinary parasitology reference manual. Ames: Iowa State University Press, pp. 173-175.

GOSWAMI, R., SOMVANSHI, R., SINGH, S.M. and SINGH, S., 2009. A preliminary survey on incidence of helminthic and protozoal diseases in rats. Indian Journal of Veterinary Pathology, vol. 33, no. 1, pp. 90-92.

HAYAT, C.S. and AKHTAR, M., 1999. Parasitic diagnosis. 1st ed. Islamabad: University Grants Commission, pp. 15-27; 64-72.

HEICHER, D.S. and GALLATI, W.W., 1978. Three new hosts for the cysticercoid of Hymenolepis diminuta. The Ohio Journal of Science, vol. 78, pp. 149-151.

KASSA, M. and ASSEFA, T., 2000. Prevalence of intestinal helminthic infections among household rats in Addis Ababa. SINET: An Ethiopian Journal of Science, vol. 23, no. 1, pp. 115-120. http:// dx.doi.org/10.4314/sinet.v23i1.18161.

KHAN, W. and KHAN, A., 2015. Diversity of intestinal parasites in male and female students and workers of Education Department of Swat, Pakistan. Pakistan Journal of Zoology, vol. 47, no. 2, pp. 565-568.

KHAN, W., KHAN, J., KHAN, N., IQBAL, R., ULLAH, A., GHAFFAR, R., MEHMOOD, S.A., AHMAD, S., KHAN, S. and ULLAH, F., 2019b. Soil-transmitted helminth infections in school children of three districts of Malakand region, Khyber Pakhtunkhwa, Pakistan. Pakistan Journal of Pharmaceutical Sciences, vol. 32, no. 2, suppl., pp. 799-803. PMid:31103975.

KHAN, W., KHAN, N.I., BUKHARI, S.N.F. and BEGUM, N., 2019a. Prevalence of intestinal parasitic infection among drug addicts in District Swat, Khyber Pakhtunkhwa, Pakistan. Iranian Journal of Parasitology, vol. 14, no. 2, pp. 359-361. PMid:31543928.

KHAN, W., NISA, N. and KHAN, A., 2017a. Prevalence and risk factors associated with intestinal parasitic infections among food handlers of Swat, Khyber Pakhtunkhwa, Pakistan.Journal of Food and Nutrition Research, vol. 5, no. 5, pp. 331-336. http:// dx.doi.org/10.12691/jfnr-5-5-7.

KHAN, W., NISA, N. and KHAN, A., 2017b. Soil transmitted helminthiasis in different occupational groups in Swat, Khyber Pakhtunkhwa, Pakistan. Pakistan Journal of Pharmaceutical Sciences, vol. 3, no. 4, pp. 1345-1350. PMid:29039336.

KHAN, W., NISA, N.-U. and NAWAZ, M.A., 2018a. Incidence of tapeworm infection in human population of Swat, Pakistan: an occupation based study. Pakistan Journal of Zoology, vol. 50, no. 2, pp. 639-645. http://dx.doi.org/10.17582/journal. pjz/2018.50.2.639.645.

KHAN, W., UN-NISA, N. and KHAN, A., 2018b. Prevalence of potentially important intestinal pathogenic protozoan parasitic infections in different occupational groups of Swat, Pakistan. Pakistan Journal of Zoology, vol. 50, no. 1. http://dx.doi. org/10.17582/journal.pjz/2018.50.1.123.129.

KHAN, W., NOOR-UN-NISA and KHAN, A., 2011. An investigation of incidence of intestinal parasites in under and above 15 years age in farmers of Swat, Pakistan. Proceedings of Parasitology, vol. 52, pp. 43-53.

KHATOON, N., BILQEES, F.M., JAFFERY, D.S. and RIZWANA, A.G., 2004. Histopathologic alterations associated with Syphacia sp.(Nematode) in the intestine of Nesokia indica. Turkish Journal of Zoology, vol. 28, no. 4, pp. 345-351. 
KIA, E.B., HOMAYOUNI, M.M., FARAHNAK, A., MOHEBALI, M. and SHOJAI, S., 2001. Study of endoparasites of rodents and their zoonotic importance in Ahvaz, South West Iran. Iranian Journal of Public Health, vol. 30, no. 1-2, pp. 49-52.

KUMARASINGHE, K.M.R.S., PREMAJITH, A.D.B., WIJESUNDARA R.R.M.K.K. and AJAPAKSHE, R.P.V.J., 2006. Prevalence of zoonotic blood protozoans and gastrointestinal helminthes in rats (Genus: Rattus) and mice (Genus: Mus) in Sri Lanka. In: Proceedings ofthe Peradeniya University Research Sessions, 2006, Sri Lanka. Sri Lanka: University of Peradeniya, p. 62.

MAFIANA, C.F., OSHO, M.B. and SAM-WOBO, S., 1997. Gastrointestinal helminth parasites of the black rat (Rattus rattus) in Abeokuta, southwest Nigeria. Journal of Helminthology, vol. 71, no. 3, pp. 217220. http://dx.doi.org/10.1017/S0022149X00015947. PMid:9705679.

MAKI, J. and YANAGISAWA, T., 1987. Infectivity of Hymenolepis nana eggs from faecal pellets in the rectum of mice. Journal of Helminthology, vol. 61, no. 4, pp. 341-345. http://dx.doi. org/10.1017/S0022149X00010270. PMid:3437113.

MARANGI, M., ZECHINI, B., FILETI, A., QUARANTA, G. and ACETI, A., 2003. Hymenolepis diminuta infection in a child living in the urban area of Rome, Italy.Journal of Clinical Microbiology, vol. 41, no. 8, pp. 3994-3995. http://dx.doi.org/10.1128/JCM.41.8.39943995.2003. PMid:12904439.

MUSHTAQ-UL-HASSAN, M., HUSSAIN, I., SHEHZADI, B., SHAHEEN, M., MAHMOOD, M.S., RAFIQUE, A. and MAHMOOD-UL-HASSAN, M., 2008. Occurrence of some zoonotic microorganisms in faecal matter of house rat (Rattus rattus) and house mouse (Mus musculus) trapped from various structures. Pakistan Veterinary Journal, vol. 28, no. 4, pp. 171-174.

NAMA, H.S. and PARIHAR, A., 1976. Quantitative and qualitative analysis of helminth fauna in Rattus rattus rufescens. Journal of Helminthology, vol. 50, no. 2, pp. 99-102. http://dx.doi. org/10.1017/S0022149X00027577. PMid:987094.

NOOR-UN-NISA, KHAN, W. and KHAN, A., 2012. A prevalence of intestinal parasites in male and female shepherds of Swat, Pakistan. International Journal of Biology and Biotechnology, vol. 8, no. 4, pp. 597-603.
RAFIQUE, A., RANA, S.A., KHAN, H.A. and SOHAIL, A., 2009. Prevalence of some helminths in rodents captured from different city structures including poultry farms and human population of Faisalabad, Pakistan. Pakistan Veterinary Journal, vol. 29, no. 3, pp. 141-144.

ROBERTS, T.J., 1997. The mammals of Pakistan. Karachi, Pakistan: Oxford University Press, $525 \mathrm{p}$.

ROHELA, M.T., NGUI, R., LIM, Y.A., KALAICHELVAN, B., WAN HAFIZ, W.I. and MOHD REDZUAN, A.N., 2012. A case report of Hymenolepis diminuta infection in a Malaysian child. Tropical Biomedicine, vol. 29, no. 2, pp. 224-230. PMid:22735844.

STOJCEVIC, D., MIHALJEVIC, Z. and MARINCULIC, A., 2004. Parasitological survey of rats in rural regions of Croatia. Vet. Med. Czech., vol.49, no. 3, pp. 70-74. http://dx.doi.org/10.17221/5679VETMED.

WAUGH, C.A., LINDO, J.F., FORONDA, P., ÁNGELES-SANTANA, M., LORENZO-MORALES, J. and ROBINSON, R.D., 2006. Population distribution and zoonotic potential of gastrointestinal helminths of wild rats Rattus rattus and R. norvegicus from Jamaica. The Journal of Parasitology, vol. 92, no. 5, pp. 1014-1018. http://dx.doi.org/10.1645/ GE-795R1.1. PMid:17152943.

WORLD HEALTH ORGANIZATION - WHO, 1987. Prevention and control of intestinal parasitic infections: report of a WHO Expert Committee [meeting held in Geneva from 3 to 7 March 1986]. Geneva: WHO.

YAQOOB, E., HUSSAIN, I. and RAHMAN, S.U., 2007. Molecular characterization by using random amplified polymorphic DNA (RAPD) analysis of Salmonella enteritidis isolates recovered from avian and human sources. Pakistan Veterinary Journal, vol. 27, no. 2, pp. 102-104.

YEN, C.M., WANG, J.J., LEE, J.D., CHEN, Y.P. and CHEN, E.R., 1996. Parasitic infections among wild rats from two areas of Kaohsiung. The Kaohsiung Journal of Medical Sciences, vol. 12, no. 3, pp. 145-149. PMid:8709181. 